\title{
Exogenous and endogenous functions of mining towns of the Silesian voivodeship, Poland
}

\author{
Arkadiusz Heder
}

Department of Economic Geography, Faculty of Earth Sciences, University of Silesia, Będzińska Str. 60, 41-200 Sosnowiec, Poland E-mail address: arekheder1987@gmail.com

\begin{abstract}
Towns are of particular interest to geography which examines them in various objective and theoretical aspects. The concept of function is associated with the role which a particular town plays in the area, and this function is the entirety of socio-economic activity carried out in the town. The concept of the economic base of towns, which is used in this paper, distinguishes two groups of town inhabitants, namely such whose work directly contributes to the development of the town, the so-called primary builders (exogenous), and secondary builders (endogenous) who support the first group. This article presents the results of the study of changes in the function of 30 towns in the Silesian voivodeship in which coal mining is still carried out or has ended (18 mining towns and 12 post-mining towns). These towns have different sizes: small ones (up to 20,000 inhabitants; $n=6$ ), medium ( 20 to 100 thousand inhabitants; $n=15$ ), and large (with population of over 100,000 inhabitants; $n=9$ ). The study was conducted with the use of the indirect measurement of economic base method based on the location ratio, but in a modified form - i.e. the employee surplus rate. The analysis of functional changes in the mining towns of the Silesian voivodeship was performed in five aspects, in relation to: 1) the opening of the economy indicator, with the use of data concerning employment in the exogenous and endogenous group; 2) the employee surplus rate, determining the functional type of towns according to the dominant PKD [Polish Classification of Business Activities] section on the basis of the exogenous group; 3 ) the structure of exogenous functions of towns; 4) change of the exogenous function of towns; 5) the employee surplus rate, determining the share of section $\mathrm{C}$ (mining) in the exogenous function of towns. The analysis showed that in the period of 1996-2009 there has been a change in the functional type, from industrial to service type, in 8 towns; however, mining is still the primary branch of business activity in 11 towns studied, especially in small ones. Today, many service-based towns specialise in trade ( $\mathrm{n}=7$ ), and a small group of towns specialises in non-market services $(n=4)$, which shows that the process of changes in this respect is still ongoing and the towns studied cannot be regarded as towns having a substantial share of higher-order services.
\end{abstract}

KEY WORDS: economic base, functional structure, employee surplus rate

\section{Introduction}

Determination of town on the basis of its function has a long and widespread tradition in geography, as evidenced by such commonly used terms as "commercial town," "industrial town," etc. (HARRIS, 1943; DZIEWOŃSKI, 1967; JERCZYŃSKI, 1977; SKIBA, 1988; WALKIEWICZ, 2006; SUliBORSKI, 2010). The term "function" was used in geography for the first time by F. Ratzel in the meaning used in physiology (BEAUJEU-GARNIER \& CHABOT, 1971). The concept of town function is understood as its activity as a whole, which is not only the reason of existence of the town, but also distinguishes and identifies it in the geographical region. Furthermore, the function of town is connected with the role it plays in the system of national economy and the socio-economic sphere, considered both from the viewpoint of this town and the settlement system to which it belongs (SULIBORSKI, 1983). Functions of a town can be examined in the context of place of residence and place of work, and in relation to the business and social entities, i.e. in the context of the structure of work places. Generally, activities of a town can be divided into two groups: manufacturing and services. Industry and crafts represent the basic manufacturing functions of a town. Industry contributed to the 
formation of many cities in the world: Essen, Donetsk, Chelyabinsk, Manchester, Philadelphia, Shenyang (HARRIS, 1943; WILLIAM-OLSSON, 1953; CHORIEW, 1965; LISZEWSKI \& MAIK, 2000).

Explanation of the origins and economic mechanisms of the existence and development of town is based on the study of the nature of inhabitants' activity. The first assumptions of the functional concept of town (town economic base) were created at the beginning of the $20^{\text {th }}$ century and formulated by a German economist, sociologist and economic historian, W. Sombart who introduced professional division of the active town population into exogenous and endogenous group. The concept of economic base distinguished two main groups of town inhabitants, the ones whose work directly contributes to the development of town, the socalled primary builders, and secondary builders who support the first group (SULIBORSKI, 2010). In other words, we can say that the activity aimed at the production of goods and providing services to the inhabitants and external areas represents the exogenous group in the town's economy, whereas the group of employees making a living from the production of goods and services for the needs of the town itself and its residents represents the endogenous group. The most important measure of town functions is the information about employment in particular types of socioeconomic activities conducted in the examined town, which determines the size of the economic base (DZIEWoŃSKI, 1967; SŁodCZYK, 2001; SUliBorski, 2010).

Mining is a particular type of specialisation. Among mining towns, the most numerous type are coal mining centres - the industrial function is clearly reflected in their physiognomy because of the unique landscape with mineshafts, waste rock landfills, sorting areas, washing plants and transport infrastructure. The exhaustion of coal reserves causes many negative consequences: the rise of unemployment, the escalation of the process of emigration from the town and the related reduction in town population, aggravation of social problems, poverty and crime. In many cases, together with the exhaustion of coal reserves, possibilities for the development of town exhaust as well, and the town loses its municipal rights (BEAUJEU-GARNIER \& CHABOT, 1971; ZuZAŃSKAŻYŚKO, 2006).

The intensive development of industry in the territory of Poland after World War II led to a significant transformation in the economic and socio-demographic structure of Poland, especially in the area of the Katowice and Rybnik conurbation. The processes of urbanisation are the most characteristic ones, including changes in the network and structure of towns - settlement systems and agricultural settlements turned into mining and manufacturing housing estates (RAJMAN, 1972). Coal mining was one of the main town building factors in the case of many towns belonging to the Rybnik and Katowice conurbation. The construction of mines resulted in spontaneous influx of inhabitants, growth of existing settlements and the creation of new ones. In the $19^{\text {th }}$ century, the scattering of housing estates located near coal mines and factories of the processing industry was a characteristic feature of the Katowice conurbation. The structure of the urban system was determined by the location of coal deposits and the sequence of their exploitation. New Polish industrial towns (Katowice, Sosnowiec, Zabrze and others) formed through merging and subsequent integration of multiple adjacent industrial and residential settlements (TKOCZ, 2005; LISZEWSKI \& MAIK, 2000).

The purpose of this article is to analyse the functional structure of mining towns in the Silesian voivodeship on the basis of the employee surplus rate which was used to determine the change of functional types. Additional aim of this paper is to determine the size and changes of the exogenous group, as well as to study the mining function in individual towns. The study aimed at answering the following questions: 1) Do exogenous functions dominate in the examined towns? 2) What functional type is typical for the largest group of towns and are there major changes occurring in this respect? 3) Is the share of mining towns decreasing?

The article presents mining towns with diverse development paths. Some of them formed as a result of influx of inhabitants, development of a settlement and the process of consolidation of settlements (Chorzów, Katowice, Ruda Śląska, Sosnowiec, Zabrze), while the other ones formed under the influence of mining, and changed their functional structure in the process of attachment of suburban mining settlements (Bytom, Będzin, Gliwice, Jastrzębie-Zdrój, Mysłowice, Rybnik). A large group of mining towns includes small towns which were classified as agricultural towns before the development of industry (Bieruń, Brzeszcze, Lędziny, Pszów, Radlin and Wojkowice). Most of them gained municipal rights in connection with the development of mining in their area.

\section{Study area}

The study area covers mining and post-mining towns associated with coal mining in the territory 
of the Silesian voivodeship within its current boundaries - a total of 30 towns located in the Katowice and Rybnik conurbation (Fig. 1). Among them, 6 are small towns (up to 20 thousand inhabitants): Bieruń, Radlin, Radzionków, Lędziny, Pszów and Wojkowice, 15 towns fall into the medium-sized category (20 to 100 thousand inhabitants): Jastrzębie-Zdrój, Mysłowice, Żory, Siemianowice Śląskie, Będzin, Piekary Śląskie, Świętochłowice, Wodzisław Śląski, Knurów, Czechowice-Dziedzice, Czeladź, Czerwionka-
Leszczyny, Łaziska Górne and Rydułtowy, while 9 can be classified as large centres (over 100 thousand residents): Katowice, Sosnowiec, Gliwice, Zabrze, Bytom, Ruda Śląska, Rybnik, Dąbrowa Górnicza and Chorzów. In the group of towns studied, there are 12 post-mining towns (Będzin, Chorzów, Czeladź, Czerwionka-Leszczyny, Dąbrowa Górnicza, Pszów, Radzionków, Siemianowice Śląskie, Świętochłowice, Wodzisław Śląski, Wojkowice and Żory). The remaining ones are mining towns.

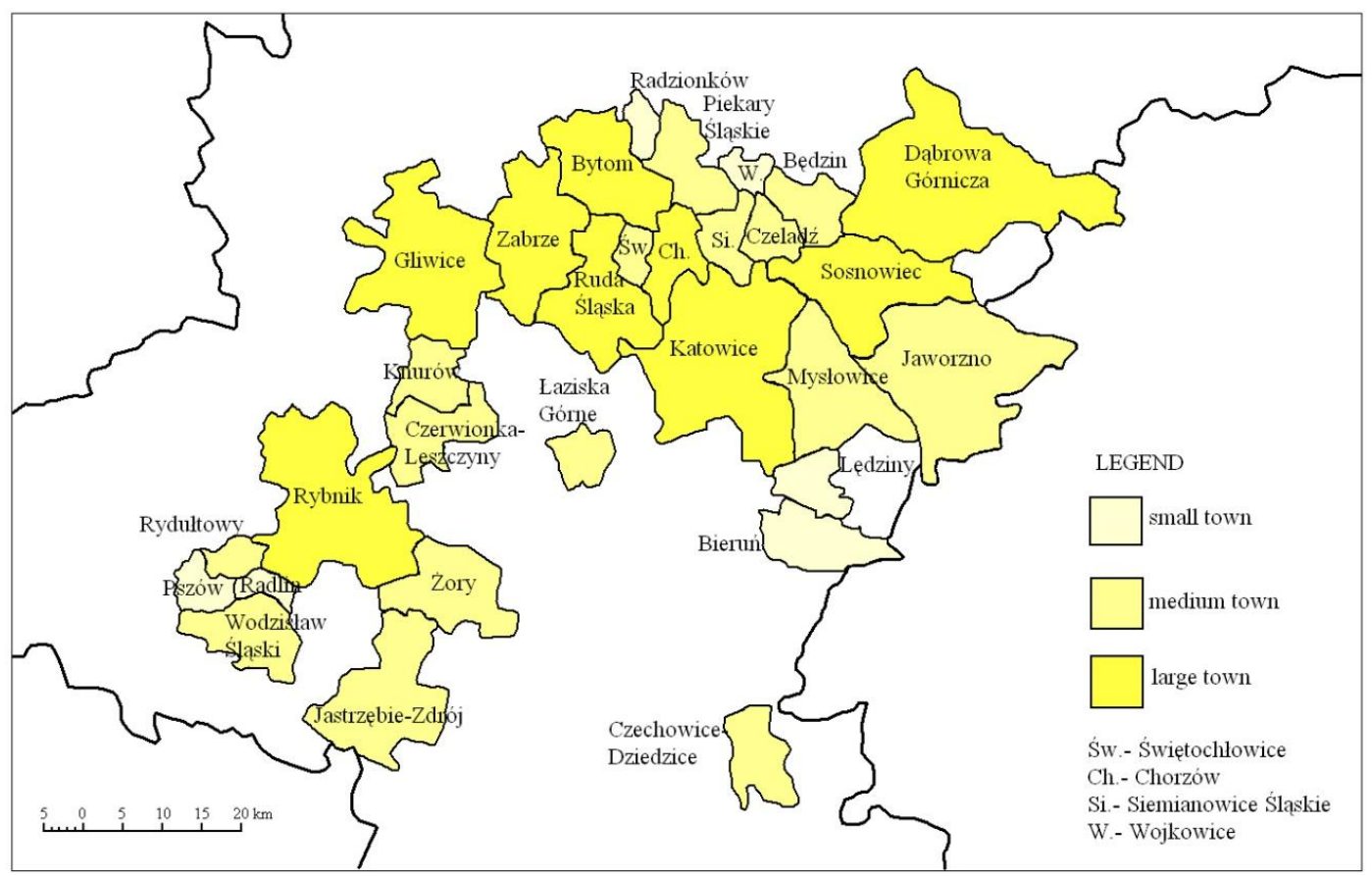

Fig. 1 Mining and post-mining towns in the Silesian voivodeship (author's compilation)

\section{Materials and methods}

Functional transformations of mining towns in the Silesian voivodeship were examined on the basis of the concept of the economic base. The methods of studying the exogenous and endogenous functions of towns were based on direct and indirect measurement of the economic base. The first method consists in examining every institution (employment establishment) located in the town and determining the nature of its business activity and the size of the exogenous and endogenous group. The second method, called indirect method, consists in determining the size of the exogenous and endogenous sector in the town on the basis of information on employment by sectors of the economy (SULIBORSKI, 2010).

Two groups of indirect methods are best known, namely the group of the smallest demands (and its variations) and one based on the location factor. In this paper, the method based on the location ratio was used, and more precisely, its modified form called the employee surplus rate developed by H. Hoyt. It is the most commonly used method, as it is possible to use it both in relation to individual towns and a collection of towns, and also allows direct calculation of surplus employment (exogenous) for each examined business activity in town, as a difference between overall employment and minimal employment (endogenous), which are determined as the product resulting from multiplying the overall employment in town by the rate showing the national (regional) share of examined business activity in the overall employment in the country (region) (DZIEWOŃSKI, 1967; JERCZYŃSKI, 1973; SULIBORSKI, 2010). This rate is presented in the form of an equation:

$$
Z_{\text {nadw }} m=Z_{i} m-\left(Z_{m} * \frac{Z_{i} k}{Z k}\right)
$$

$\mathrm{Z}_{\mathrm{im}}=$ employment in the business activity "and" in the town

$\mathrm{Z}_{\mathrm{m}}=$ total employment in the town

$\mathrm{Z}_{\mathrm{ik}}=$ employment in the business activity "and" in the country, region

$\mathrm{Z}_{\mathrm{k}}=$ total employment 
A positive rate value indicates the exogenous ("exogenous") nature, and includes business activities conducted for the external world. Functions of this kind, also called town building functions, are considered to be a factor of existence and development of town (MAIK, 1992). A negative rate value indicates that there is deficiency in a given business activity which needs to be covered by other towns. Thanks to this rate, it is possible to determine the share of exogenous and endogenous functions in particular sectors of economy in towns.

Data about the town obtained in absolute figures renders it possible to specify the structure of exogenous and endogenous functions, and to calculate basic indicators of the economic base of the town. One of them, the indicator of opening (closure) of economy was used in this study. This indicator looks as follows: ZegzM/ZendM with ZegzM=1, where: ZegzM - total exogenous employment in the town, ZendM - total endogenous employment in the town.

Another element of the analysis consisted in classifying mining towns on the basis of dominant share of individual exogenous sections (based on the employee surplus rate). Functional classification was made on the basis of typespatterns. This procedure consists in determining the classification scheme, i.e. quantitatively identifying types-patterns, and then assigning the examined towns to the previously established classes (MAIK, 1992). For the purposes of analysis, the Polish Classification of Business Activities 2004 was used for 1996 and 2009. The group of "industrial employees" include workers employed in sections from $\mathrm{C}$ to $\mathrm{F}$ (mining, industrial processing, manufacturing and supply of electricity, gas and water, construction), while the group of "service workers" is covered by sections from $G$ to $Q$ (wholesale and retail trade, hotels and restaurants, transport, warehouse management and communication, financial agency activities, real estate management, rental and services related to the conduct of business activity, public administration and defence activities, education, health care and social work, community services, social and personal services, households employing domestic personnel, extraterritorial organisations and bodies). In the first stage, the towns were classified into two types: 1) towns being industrial centres - where more than $50 \%$ of the employed of exogenous character in non-agricultural business activities represent manufacturing and construction employees; 2) towns being servicebased centres - where more than $50 \%$ of the employed of exogenous character in non- agricultural business activities represent employees of the service sector.

In the second stage, the following types of towns were distinguished: 1) industrial centres specialised in one type of activity (more than $50 \%$ of industrial employees of the exogenous group are employed in one business activity); 2) industrial centres specialised in two types of activity (more than $66.7 \%$ of industrial employees of the exogenous group are employed in two business activities).

In the case of services, slightly different criteria were applied than in the case of industry, due to the less labour-intensive nature service activity: 1) service-based centres specialised in one type of activity (more than $40 \%$ of service employees of the exogenous group are employed in one business activity); 2) service-based centres specialised in two types of activity (more than $50 \%$ of service employees of the exogenous group are employed in two business activities).

Additionally, two classes were distinguished which do not meet any of the four abovementioned criteria: 1) centres without a dominant function - industrial (over 50\% of employees of the exogenous group are employed in industry); 2) centres without a dominant function - servicebased (over $50 \%$ of employees of the exogenous group are employed in services).

Output data for the analysis were collected from the reports and data of the Central Statistical Office for the years 1991, 1996, 2002, 2006 and 2009.

\section{Results and discussion}

The analysis of functional changes in the mining towns was performed in five aspects, in relation to: 1) the opening of the economy indicator, with the use of data concerning employment in the exogenous and endogenous group; 2 ) the employee surplus rate, determining the functional type of towns according to the dominant PKD [Polish Classification of Business Activities] section on the basis of the exogenous group; 3 ) the structure of exogenous functions of mining towns; 4) change of the exogenous function of mining towns in absolute numbers and percentages; 5) the employee surplus rate, determining the share of section C mining in the exogenous function of towns.

\subsection{Opening of the town economy indicator}

Analysing the average values of the economic base indicator (the opening of the economy indicator) (Zegz/Zend) (Tab. 1), a large variation of obtained results can be observed which 
indicates differences in the type of economic base of the towns. It was tightly closed in Bytom and Sosnowiec (average rate of more than 8 points, the exogenous sector covering on average only $10 \%$ and $11 \%$ of the total employment in town, respectively), and closed, among others, in Katowice, Gliwice, Rybnik and Zabrze (average rate of 5-7 points, and the exogenous sector covering on average $12-16 \%$ of the total employment in town). On the other hand, the economic base was very open, among others, in
Radlin, Bieruń, Pszów and Lędziny (the average rate of economic base did not exceed 3 points, and the exogenous sector covered on average 45$55 \%$ of the total employment of the abovementioned towns). Large towns are characterised by a high rate of economic base (closed economy), except for the town of Ruda Śląska, while small towns are characterised by a low rate of economic base (opening of the economy), with the exception of Wojkowice which is a post-mining town.

Table 1. Changes of the economic base rate of mining towns in the Silesian voivodeship (author's compilation)

\begin{tabular}{|c|c|c|c|c|c|c|}
\hline Town & 1991 & 1996 & 2002 & 2006 & 2009 & Average rate \\
\hline Bytom & 11.0 & 10.9 & 9.6 & 7.1 & 7.9 & 9.3 \\
\hline Sosnowiec & 11.5 & 8.2 & 7.2 & 6.6 & 8.7 & 8.4 \\
\hline Zabrze & 10.9 & 7.6 & 7.6 & 6.4 & 7.0 & 7.9 \\
\hline Rybnik & 11.1 & 7.1 & 5.9 & 5.2 & 6.9 & 7.2 \\
\hline Jaworzno & 7.7 & 4.0 & 7.6 & 4.6 & 10.9 & 7.0 \\
\hline Siemianowice Śląskie & 7.8 & 4.8 & 6.5 & 6.4 & 8.5 & 6.8 \\
\hline Gliwice & 4.6 & 4.9 & 6.5 & 6.7 & 7.7 & 6.1 \\
\hline Żory & 4.6 & 5.2 & 4.9 & 5.5 & 6.8 & 5.4 \\
\hline Katowice & 4.5 & 4.9 & 7.0 & 5.6 & 4.9 & 5.4 \\
\hline Radzionków & $\mathrm{x}$ & $\mathrm{x}$ & 4.8 & 5.2 & 4.5 & 4.8 \\
\hline Chorzów & 2.5 & 3.1 & 4.0 & 7.9 & 6.5 & 4.8 \\
\hline Czeladź & 5.4 & 3.2 & 5.3 & 4.3 & 5.5 & 4.7 \\
\hline Będzin & 2.5 & 4.3 & 5.0 & 4.8 & 5.9 & 4.5 \\
\hline Świętochłowice & 4.4 & 2.4 & 6.0 & 5.0 & 4.4 & 4.4 \\
\hline Mysłowice & 3.7 & 3.4 & 5.3 & 4.2 & 5.3 & 4.4 \\
\hline Czechowice-Dziedzice & 2.4 & 2.2 & 3.8 & 4.5 & 6.7 & 3.9 \\
\hline Wodzisław Śląski & 2.6 & 4.6 & 3.9 & 2.6 & 5.1 & 3.8 \\
\hline Wojkowice & $\mathrm{x}$ & 0.9 & 3.8 & 5.5 & 4.3 & 3.6 \\
\hline Dąbrowa Górnicza & 1.8 & 1.4 & 4.6 & 6.1 & 3.8 & 3.5 \\
\hline Piekary Śląskie & 2.7 & 3.0 & 3.8 & 3.8 & 4.3 & 3.5 \\
\hline Łaziska Górne & 2.4 & 2.3 & 3.6 & 3.2 & 3.9 & 3.1 \\
\hline Ruda Śląska & 2.8 & 2.6 & 3.1 & 2.8 & 3.6 & 3.0 \\
\hline Jastrzębie-Zdrój & 3.0 & 2.2 & 2.8 & 2.3 & 2.7 & 2.6 \\
\hline Czerwionka-Leszczyny & 1.7 & 1.7 & 3.2 & 3.0 & 3.1 & 2.5 \\
\hline Rydułtowy & $\mathrm{x}$ & 1.5 & 1.5 & 1.5 & 1.6 & 1.5 \\
\hline Knurów & 1.4 & 1.4 & 1.5 & 1.6 & 1.5 & 1.5 \\
\hline Radlin & $\mathrm{x}$ & $\mathrm{x}$ & 1.5 & 1.6 & 1.3 & 1.5 \\
\hline Bieruń & 1.4 & 1.4 & 1.4 & 1.4 & 1.2 & 1.4 \\
\hline Pszów & $\mathrm{x}$ & 1.1 & 1.1 & 1.1 & 1.3 & 1.2 \\
\hline Lędziny & 0.6 & 0.7 & 0.9 & 1.0 & 0.9 & 0.8 \\
\hline
\end{tabular}

Key: Zegz/Zend Zegz=1; Zegz- employment, exogenous group; Zend- employment, endogenous group

The process of change of the economic base rate is different for every town and has its own distinct character. In several towns, among others in Jaworzno, Siemianowice, Czeladź, and to a certain extent also in Żory and Katowice, where the indicator shows high values (closed economy), the changes have a cyclical form. Towns with the highest value of the closing of the economy indicator (Bytom, Sosnowiec, Zabrze and Rybnik) show a directional- linear character of changes (decrease in the indicator value), however, in the last year studied, all towns show a trend of indicator growth. Towns in which average economic base rate amounts to 1.5 or less 
(Rydułtowy, Knurów, Radlin, Bieruń, Pszów and Lędziny) show a very low volatility of rate value.

A study of the changes of the economic base indicators in different towns belonging to a specified group, or a settlement system, enables the researcher to compare the nature of the economic bases and the course of their transformation. In similar studies of selected towns in Poland, SULIBORSKI (2010) formulated two research hypotheses. The process of change of the economic base of towns (the functional structure) is dependent on its character. In the case of structures dominated by endogenous sector (closed economies), it has the form of cyclic processes, while in structures with dominating exogenous sector (open economies), it is more a directional process. In the studies of mining towns carried out for the purposes of this article, this hypothesis is not fully confirmed, as changes in the structures of towns characterised by the closed economy are both directional and cyclical. The reasons may be related to the diversification of the functional structure of individual towns. Closed functional structures exhibit high changeability, while the more open structures are characterised by greater stability of behaviours (SUliBORSKI, 2010). A similar situation can also be observed in the group of mining towns studied. This may be due to a greater stability of the exogenous function (in this case, primarily associated with mining), which is dependent and deeply rooted in the national settlement system, which positions the town in the system for a long time (SULIBORSKI, 2010).

\subsection{Functional type of towns}

Considering the changes in the functional structure of towns (in terms of the exogenous group) which have occurred over the past several years (1996 to 2009) (Tab. 2), one can observe their high intensity. In 1996, the most dominant group was represented by industrial towns (sections C-F), and there were 23 of them, whereas only 5 towns belonged to the servicebased town category (sections G-Q). The changes, which took place during the studied period, were reflected by decline in the share of industrial towns to 15 , and the increase in the number of service-based towns to 13 .

In 1996, as many as 15 of the towns studied had mining functions, and in fourteen of them mining was a leading function. In Bierun and Lędziny, the mining section accounted for $100 \%$ of the exogenous group, while in other towns, mining constituted from $63 \%$ in Mysłowice to over 99\% in Pszów. Five towns - i.e. CzechowiceDziedzice, Chorzów, Dąbrowa Górnicza, Siemianowice Śląskie and Świętochłowice - were distinguished by their industrial processing function. Out of the five service-based towns, two were characterized by the lack of a dominant function (Czeladź and Sosnowiec), while the other three were distinguished by specific functions: real estate management (Gliwice), trade/real estate management (Katowice), education/health care and social work (Żory). Of the five towns mentioned, the share of the service sector (in terms of the exogenous group) was the highest in Żory $(93.2 \%)$ and Katowice (92.8\%), and the lowest (53.9\%) in Sosnowiec.

In 2009, a very high increase in the service sector contributed to the shift in the functional types of the towns studied. The number of towns having the mining and industrial processing function decreased to 11 and 2, respectively. However, the mining function still constituted a significant share in the exogenous group, accounting for $53.1 \%$ in Rybnik, up to $97.7 \%$ in Knurów and $100 \%$ in Bieruń and Lędziny. In 2009 , the number and functional diversification of service-based towns increased significantly. Out of 13 service-based towns, 7 performed trade functions, and in as many as 6 towns, trade was the leading function. Remaining service functions distinguishing the towns studied included: administration (Wojkowice and Katowice) and real estate management (Gliwice and Chorzów).

To conclude, it can be stated that the increase in the share of service function in the towns studied is progressing. However, there is a group of towns in which the industrial function is stable. Three groups of towns could be distinguished. In towns belonging to the first group, their function changed from industrial to service function (Wojkowice, Będzin, Świętochłowice, Wodzisław Śląski, Czerwionka-Leszczyny, Zabrze, Bytom and Chorzów). This change occurred due to the closure of many mines and steelworks. The second group included towns with stabilised industrial function in both periods studied (Bieruń, Lędziny, Pszów, Jaworzno, Jastrzębie-Zdrój, Mysłowice, Siemianowice Śląskie, Piekary Śląskie, Knurów, Czechowice-Dziedzice, Łaziska Górne, Rydułtowy, Ruda Śląska, Rybnik and Dąbrowa Górnicza). The third group consisted of towns with dominant service function in both periods (Żory, Czeladź, Katowice, Sosnowiec and Gliwice). 
Table 2. Functional specialisation of mining towns in the Silesian voivodeship by exogenous group in 1996 and 2009 , divided by individual sections of business activity (author's compilation)

\begin{tabular}{|c|c|c|}
\hline $\begin{array}{l}\text { Type of town according to the dominant PKD } \\
\text { section }\end{array}$ & 1996 & 2009 \\
\hline Mining (C) & $\begin{array}{l}\text { Bieruń, Bytom, Czerwionka-Leszczyny, } \\
\text { Jastrzębie-Zdrój, Knurów, Lędziny, } \\
\text { Mysłowice, Piekary Śląskie, Pszów, } \\
\text { Ruda Śląska, Rydułtowy, Wodzisław } \\
\text { Śląski, Wojkowice }\end{array}$ & $\begin{array}{l}\text { Bieruń, Jastrzębie-Zdrój, } \\
\text { Lędziny, Łaziska Górne, } \\
\text { Knurów, Mysłowice, Piekary } \\
\text { Śląskie, Pszów, Ruda Śląska, } \\
\text { Rybnik, Rydułtowy }\end{array}$ \\
\hline Industrial processing (D) & $\begin{array}{l}\text { Czechowice-Dziedzice, Chorzów, } \\
\text { Dąbrowa Górnicza, Siemianowice } \\
\text { Śląskie, Świętochłowice }\end{array}$ & $\begin{array}{l}\text { Czechowice-Dziedzice, } \\
\text { Dąbrowa Górnicza }\end{array}$ \\
\hline $\begin{array}{l}\text { Manufacturing and supply of electricity, gas } \\
\text { and water (E) }\end{array}$ & Będzin & - \\
\hline $\begin{array}{l}\text { Manufacturing and supply of electricity, gas } \\
\text { and water - mining (E-C) }\end{array}$ & Jaworzno & - \\
\hline $\begin{array}{l}\text { Mining - manufacturing and supply of } \\
\text { electricity, gas and water (C-E) }\end{array}$ & Łaziska Górne & - \\
\hline Industrial town - no dominant function & Rybnik, Zabrze & Jaworzno, Siemianowice Śląskie \\
\hline Wholesale and retail trade $(G)$ & - & Czeladź \\
\hline $\begin{array}{l}\text { Real estate services, rental and services } \\
\text { related to the conduct of business activity }(\mathrm{K})\end{array}$ & Gliwice & Gliwice \\
\hline Public administration and defence activities (L) & - & Wojkowice \\
\hline $\begin{array}{l}\text { Wholesale and retail trade - hotels and } \\
\text { restaurants }(\mathrm{G}-\mathrm{H})\end{array}$ & - & Żory \\
\hline $\begin{array}{l}\text { Wholesale and retail trade - real estate } \\
\text { services, rental and services related to the } \\
\text { conduct of business activity }(\mathrm{G}-\mathrm{K})\end{array}$ & Katowice & Będzin, Sosnowiec \\
\hline Wholesale and retail trade - education (G-M) & - & $\begin{array}{l}\text { Czerwionka-Leszczyny, } \\
\text { Wodzisław Śląski }\end{array}$ \\
\hline $\begin{array}{l}\text { Transport, warehouse management and } \\
\text { communication - wholesale and retail trade (I-G) }\end{array}$ & - & Świętochłowice \\
\hline $\begin{array}{l}\text { Real estate services, rental and services } \\
\text { related to the conduct of business activity - } \\
\text { transport, warehouse management and } \\
\text { communication (K-I) }\end{array}$ & - & Chorzów \\
\hline Education - health care and social work (M-N) & Żory & - \\
\hline $\begin{array}{l}\text { Public administration and defence activities - } \\
\text { real estate services, rental and services related } \\
\text { to the conduct of business activity (L-K) }\end{array}$ & - & Katowice \\
\hline Service-based town - no dominant function & Czeladź, Sosnowiec & Bytom, Zabrze \\
\hline
\end{tabular}

\subsection{The structure of the exogenous functions of towns}

Both in 1996 and 2009, mining towns of the Silesian voivodeship were characterised by a very diversified share of the exogenous group in terms of the number of exogenous sections, as well as the percentage share (Tab. 3). In 1996, the share of the exogenous sector ranged from $8.4 \%$ in Bytom to $59.8 \%$ in Lędziny. In 2009, it ranged from $8.4 \%$ in Jaworzno to $53.1 \%$ in Lędziny.

In 1996, the greatest diversity of the functional structure of the exogenous sector was observed in Chorzów (10 functions), - second greatest in Czeladź and Zabrze (9 functions each), and subsequently Katowice, Rybnik, Sosnowiec, Wodzisław Śląski and Żory (8 functions each). Bieruń and Lędziny were characterised by the smallest diversification of exogenous functions (1 function, i.e. mining each). Mining was the most popular section, as it was represented in as many as 14 towns, followed by the construction industry in 12 towns. In contrast, the public administration and defence activities, and education sections were present only in a few towns.

In the analysed period (1996-2009), changes were observed in the number of sections of "export" (exogenous) character in individual towns. Increase in the number of exogenous sections took place in 12 towns, and the highest increase occurred in Bytom, Czerwionka-Leszczyny, Piekary Śląskie and Wojkowice (by 4 sections). In 5 towns, the number of exogenous sections remained unchanged, while in 9 towns there was a decline in the number of sections. Compared to 1996, the decline was observed in the field of: industrial 
processing, which in 1996 was present in 11 towns, and in 2009 only in 7; manufacturing and the supply of electricity, gas and water (decrease from 11 to 8 towns). The mining section in both periods of time was represented in 14 towns. This indicates a stable position of this section, which is still having a very large impact on the functional structure of many towns studied. Increase occurred in the construction section (from 12 to 16 towns), and in the services sections: trade (from 11 to 15 towns), hotels and restaurants (from 10 to 15 towns), transport, warehouse management and communication (from 7 to 12 towns), and in the education section (from 5 to 9 towns). These changes show that there is an increasing diversification of the exogenous group structure.

Table 3. Structure of exogenous functions of towns in the Silesian voivodeship in 1996 and 2009 (author's compilation)

\begin{tabular}{|c|c|c|c|c|}
\hline \multirow[b]{2}{*}{ Town } & \multicolumn{2}{|r|}{1996} & \multicolumn{2}{|r|}{2009} \\
\hline & $\begin{array}{l}\text { Number of } \\
\text { exogenous } \\
\text { functions }\end{array}$ & $\begin{array}{l}\text { Sections of exogenous } \\
\text { character }\end{array}$ & $\begin{array}{l}\text { Number of } \\
\text { exogenous } \\
\text { functions }\end{array}$ & $\begin{array}{c}\text { Sections of exogenous } \\
\text { character }\end{array}$ \\
\hline Będzin & 6 & $\mathrm{D}, \mathrm{E}, \mathrm{I}, \mathrm{L}, \mathrm{N}, \mathrm{O}$ & 8 & $E, F, G, H, J, K, N, O$ \\
\hline Bieruń & 1 & $\mathrm{C}$ & 1 & $\mathrm{C}$ \\
\hline Bytom & 4 & $\mathrm{C}, \mathrm{G}, \mathrm{N}, \mathrm{O}$ & 8 & $\mathrm{C}, \mathrm{F}, \mathrm{G}, \mathrm{H}, \mathrm{K}, \mathrm{M}, \mathrm{N}, \mathrm{O}$ \\
\hline Chorzów & 10 & A, D, E, F, G, H, I, J, N, O & 9 & $\mathrm{~B}, \mathrm{E}, \mathrm{F}, \mathrm{G}, \mathrm{H}, \mathrm{I}, \mathrm{K}, \mathrm{N}, \mathrm{O}$ \\
\hline Czechowice-Dziedzice & 3 & $\mathrm{D}, \mathrm{H}, \mathrm{I}$ & 6 & B, C, D, F, G, I \\
\hline Czeladź & 9 & B, D, E, F, G, J, K, M, N & 6 & $F, G, H, I, J, M$ \\
\hline Czerwionka-Leszczyny & 4 & $\mathrm{C}, \mathrm{E}, \mathrm{H}, \mathrm{O}$ & 8 & $A, F, G, H, I, J, M, O$ \\
\hline Dąbrowa Górnicza & 3 & $\mathrm{D}, \mathrm{F}, \mathrm{H}$ & 4 & $\mathrm{D}, \mathrm{E}, \mathrm{F}, \mathrm{I}$ \\
\hline Gliwice & 7 & $\mathrm{D}, \mathrm{F}, \mathrm{G}, \mathrm{I}, \mathrm{J}, \mathrm{K}, \mathrm{M}$ & 4 & $\mathrm{D}, \mathrm{F}, \mathrm{K}, \mathrm{M}$ \\
\hline Jastrzębie-Zdrój & 5 & $\mathrm{C}, \mathrm{E}, \mathrm{F}, \mathrm{H}, \mathrm{N}$ & 2 & $\mathrm{C}, \mathrm{O}$ \\
\hline Jaworzno & 3 & $\mathrm{C}, \mathrm{E}, \mathrm{I}$ & 5 & $\mathrm{C}, \mathrm{D}, \mathrm{I}, \mathrm{J}, \mathrm{M}$ \\
\hline Katowice & 8 & $\mathrm{~F}, \mathrm{G}, \mathrm{H}, \mathrm{I} J, \mathrm{~K}, \mathrm{~L}, \mathrm{O}$ & 6 & E, J, K, L, N, O \\
\hline Knurów & 2 & $\mathrm{C}, \mathrm{H}$ & 2 & $\mathrm{C}, \mathrm{J}$ \\
\hline Lędziny & 1 & $\mathrm{C}$ & 1 & $\mathrm{C}$ \\
\hline Łaziska Górne & 4 & C, D, E, F & 4 & $\mathrm{C}, \mathrm{D}, \mathrm{H}, \mathrm{M}$ \\
\hline Mysłowice & 3 & $\mathrm{C}, \mathrm{F}, \mathrm{K}$ & 3 & $\mathrm{C}, \mathrm{F}, \mathrm{H}$ \\
\hline Piekary Śląskie & 2 & $\mathrm{C}, \mathrm{N}$ & 6 & $\mathrm{C}, \mathrm{E}, \mathrm{G}, \mathrm{H}, \mathrm{N}, \mathrm{O}$ \\
\hline Pszów & 3 & $\mathrm{C}, \mathrm{H}, \mathrm{O}$ & 4 & C, H, I, O \\
\hline Radlin & $\mathrm{x}$ & - & 2 & $\mathrm{C}, \mathrm{E}$ \\
\hline Radzionków & $\mathrm{x}$ & - & 6 & $\mathrm{D}, \mathrm{F}, \mathrm{G}, \mathrm{H}, \mathrm{L}, \mathrm{O}$ \\
\hline Ruda Śląska & 2 & $\mathrm{C}, \mathrm{E}$ & 3 & $\mathrm{C}, \mathrm{N}, \mathrm{O}$ \\
\hline Rybnik & 8 & $\mathrm{~B}, \mathrm{C}, \mathrm{E}, \mathrm{F}, \mathrm{I}, \mathrm{J}, \mathrm{N}, \mathrm{O}$ & 7 & C, E, F, G, H, I, N \\
\hline Rydułtowy & 2 & $\mathrm{C}, \mathrm{N}$ & 4 & $\mathrm{C}, \mathrm{H}, \mathrm{N}, \mathrm{O}$ \\
\hline Siemianowice Śląskie & 4 & $\mathrm{D}, \mathrm{G}, \mathrm{K}, \mathrm{N}$ & 5 & $\mathrm{D}, \mathrm{F}, \mathrm{G}, \mathrm{H}, \mathrm{K}$ \\
\hline Sosnowiec & 8 & $\mathrm{~B}, \mathrm{D}, \mathrm{G}, \mathrm{H}, \mathrm{J}, \mathrm{K}, \mathrm{M}, \mathrm{N}$ & 6 & B, F, G, I, K, N \\
\hline Świętochłowice & 7 & $\mathrm{D}, \mathrm{E}, \mathrm{F}, \mathrm{G}, \mathrm{K}, \mathrm{N}, \mathrm{O}$ & 6 & $\mathrm{~F}, \mathrm{G}, \mathrm{H}, \mathrm{I}, \mathrm{N}, \mathrm{O}$ \\
\hline Wodzisław Śląski & 8 & $A, B, C, G, J, L, M, N$ & 6 & $\mathrm{G}, \mathrm{H}, \mathrm{L}, \mathrm{M}, \mathrm{N}, \mathrm{O}$ \\
\hline Wojkowice & 2 & $\mathrm{C}, \mathrm{L}$ & 6 & $F, G, I, L, M$ \\
\hline Zabrze & 9 & $\mathrm{D}, \mathrm{E}, \mathrm{F}, \mathrm{G}, \mathrm{J}, \mathrm{K}, \mathrm{M}, \mathrm{N}, \mathrm{O}$ & 7 & E, F, G, I, K, N, O \\
\hline Żory & 8 & $\mathrm{~B}, \mathrm{~F}, \mathrm{G}, \mathrm{H}, \mathrm{L}, \mathrm{M}, \mathrm{N}, \mathrm{O}$ & 5 & $\mathrm{~F}, \mathrm{G}, \mathrm{H}, \mathrm{M}, \mathrm{O}$ \\
\hline
\end{tabular}

\subsection{Changes of the exogenous functions of towns}

While analysing the sizes of the exogenous group of towns studied in the years 1996-2009 (Tab. 4), it can be concluded that in 23 out of 28 towns studied, the number of employees in the exogenous group in percentages decreased, and the biggest drop was recorded in Wojkowice,
Dąbrowa Górnicza and Czechowice-Dziedzice. In these towns, the decrease was caused by the restructuring of heavy industries - the industrial processing section (D) in the case of Dąbrowa Górnicza (ArcelorMittal Poland), CzechowiceDziedzice (refinery), and the decommissioning of the mining industry in Wojkowice. This phenomenon is disadvantageous, because the shortage of 
exogenous functions means too small inflow of external capital to the market of a particular town, which may contribute to limited investment possibilities and development of towns in the following years (RAJCHEL, 2001). Exogenous activity (i.e. "export" activity) is the essence of the existence of a town (JERCZYŃSKI, 1973). The economic strength of towns and their growth are conditioned by the development of the exogenous sector, which is equipped with the multiplier development mechanism and produces impulse for development in the entire economy of the town (ТкосZ, 2006; МАIK, 1992). The increase in the percentage share of the size of exogenous group was observed in Bieruń, Bytom, Zabrze, Rybnik and Katowice. In Rybnik and Bieruń, this increase resulted from the stable situation of mining (the "Piast" mine in Bierun is the second largest mine in Poland in terms of employment and production). In Bytom, the "exogeneity" increased in the construction and trade section, in Zabrze - in the health care and social works section, whereas in Katowice there was a significant increase of the exogenous group in the administration section, as well as real estate management and financial agency activities.

Table 4. Changes of the exogenous function in mining towns of the Silesian voivodeship (author's compilation)

\begin{tabular}{|c|c|c|}
\hline \multirow{2}{*}{ Town } & \multicolumn{2}{|c|}{$\begin{array}{l}\text { Change in the size of exogenous } \\
\text { group (1996-2009) }\end{array}$} \\
\hline & $\begin{array}{c}\text { in absolute } \\
\text { numbers }\end{array}$ & in $\%$ \\
\hline Będzin & -341 & -4.3 \\
\hline Bieruń & 688 & 3.9 \\
\hline Bytom & 1284 & 2.8 \\
\hline Chorzów & -2544 & -11.1 \\
\hline Czechowice-Dziedzice & -2864 & -18.0 \\
\hline Czeladź & -21 & -8.3 \\
\hline Czerwionka-Leszczyny & -831 & -13.0 \\
\hline Dąbrowa Górnicza & -7225 & -20.3 \\
\hline Gliwice & -580 & -5.4 \\
\hline Jastrzębie-Zdrój & -1799 & -4.7 \\
\hline Jaworzno & -2368 & -11.7 \\
\hline Katowice & 13076 & 0.2 \\
\hline Knurów & -2434 & -1.5 \\
\hline Lędziny & -2147 & -6.7 \\
\hline Łaziska Górne & -1724 & -10.0 \\
\hline Mysłowice & -618 & -6.5 \\
\hline Piekary Śląskie & -680 & -6.2 \\
\hline Pszów & -755 & -4.9 \\
\hline Radlin & $\mathrm{x}$ & $\mathrm{x}$ \\
\hline Radzionków & $\mathrm{x}$ & $\mathrm{x}$ \\
\hline Ruda Śląska & -2746 & -6.1 \\
\hline Rybnik & 1564 & 0.4 \\
\hline Rydułtowy & 215 & -1.2 \\
\hline Siemianowice Śląskie & -593 & -6.7 \\
\hline Sosnowiec & 1662 & -0.6 \\
\hline Świętochłowice & -893 & -10.8 \\
\hline Wodzisław Śląski & -1552 & -1.5 \\
\hline Wojkowice & -1044 & -32.7 \\
\hline Zabrze & 2489 & 0.9 \\
\hline Żory & 822 & -3.3 \\
\hline
\end{tabular}


4.5. Share of section C (mining) in the exogenous function of towns

Section C (mining) deserves particular attention (Tab. 5). Mining towns can be divided into four groups according to the share of section C (mining) in their exogenous function. The first group consists of towns in which the share of mining in 2009 exceeded $80 \%$. These are mainly small towns, however this group also includes medium and large towns, such as Jastrzębie-Zdrój and Ruda Śląska. The second group consists of towns with the participation of mining in the exogenous function of up to $80 \%$. This group includes both mediumsized and large towns. The third group consists of towns in which mining did not have exogenous character (except for Zabrze in 1991). The fourth group is now represented by post-mining towns.

Table 5. Percentage share of section C - mining in the exogenous function (in terms of group) of towns in the Silesian voivodeship (author's compilation)

\begin{tabular}{|c|c|c|c|c|c|}
\hline Town & 1991 & 1996 & 2002 & 2006 & 2009 \\
\hline Lędziny & 100 & 100 & 100 & 100 & 100 \\
\hline Bieruń & 100 & 100 & 92.9 & 99.8 & 100 \\
\hline Knurów & 100 & 99.6 & 100 & 97.7 & 97.7 \\
\hline Radlin & $\mathrm{x}$ & $\mathrm{x}$ & 92.5 & 97.8 & 97.7 \\
\hline Jastrzębie-Zdrój & 100 & 96.8 & 86.8 & 85.5 & 96.5 \\
\hline Łaziska Górne & 52.5 & 47.8 & 97.8 & 75.9 & 94.9 \\
\hline Pszów & $\mathrm{x}$ & 99.3 & 100 & 97.2 & 90.7 \\
\hline Rydułtowy & $\mathrm{x}$ & 89.4 & 80.8 & 76.9 & 89.5 \\
\hline Ruda Śląska & 94.4 & 98.4 & 93 & 83.6 & 86.1 \\
\hline Mysłowice & 63.8 & 63.0 & 97.4 & 61.8 & 75.2 \\
\hline Piekary Śląskie & 96.3 & 96.1 & 65.9 & 73.1 & 63.2 \\
\hline Rybnik & 9.4 & 20.1 & 35.2 & 36.8 & 53.1 \\
\hline Jaworzno & 68.4 & 39.7 & 7.4 & 23.8 & 35.6 \\
\hline Bytom & 57.3 & 65.4 & 6.3 & 10.7 & 8.7 \\
\hline Czechowice-Dziedzice & - & - & - & - & 5.9 \\
\hline Zabrze & 24.4 & - & - & - & - \\
\hline Gliwice & - & - & - & - & - \\
\hline Katowice & - & - & - & - & 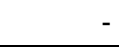 \\
\hline Sosnowiec & - & - & - & - & - \\
\hline Czerwionka-Leszczyny & 98.7 & 88.5 & PM & PM & PM \\
\hline Wodzisław Śląski & 97.2 & 82.1 & PM & PM & PM \\
\hline Czeladź & 29.0 & - & PM & PM & PM \\
\hline Żory & 19.8 & - & $\mathrm{PM}$ & PM & PM \\
\hline Wojkowice & $\mathrm{x}$ & 94.4 & $\mathrm{PM}$ & PM & PM \\
\hline Będzin & - & - & PM & PM & PM \\
\hline Chorzów & - & PM & PM & PM & PM \\
\hline Dąbrowa Górnicza & - & PM & PM & PM & PM \\
\hline Siemianowice Śląskie & - & - & $\mathrm{PM}$ & $\mathrm{PM}$ & PM \\
\hline Świętochłowice & - & PM & PM & PM & PM \\
\hline Radzionków & $\mathrm{x}$ & $\mathrm{x}$ & $\mathrm{PM}$ & PM & PM \\
\hline
\end{tabular}

Key: PM - post-mining town

Mining constitutes an essential section forming the exogenous function in many of the towns studied, primarily small ones, up to 20 thousand inhabitants. In Lędziny and Bieruń, mining accounted for $100 \%$ of the exogenous function. This results from the lack of economic entities with a similar level of employment, as well as the size of the "Ziemowit" and "Piast" mines which belong to the group of four largest mines in Poland (employing 4.7 and 6.0 thousand employees, respectively). Substantial share of mining in large towns - Jastrzębie-Zdrój and Ruda Śląska is a 
very interesting fact, due to reduced production and employment in all mines in the 21st century, and continuously increasing development of service functions of towns, especially large ones. Another group is formed by Katowice, Gliwice, Sosnowiec and Zabrze where mining does not have the exogenous character. These centres are characterized by the largest labour market (over 70,000 employees), and a significant share of service sections (J-N) in the creation of the exogenous function.

In many towns, the share of mining in the exogenous function throughout the studied period is stable (e.g. in Lędziny, Bieruń, Knurów, JastrzębieZdrój, Ruda Śląska, Radlin and Rydułtowy), and it cannot be stated that the role played by mining in the creation of functional structure in the case of the above-mentioned towns is decreasing. However, in some towns mining has a fluctuating character (Łaziska Górne, Mysłowice), whereas in Bytom it is recessive. Fluctuations result from the temporary high share of other exogenous sections (in the case of Łaziska Górne, in 1991 it was the industry section, in 1996 supply of electricity, gas and water (E), and in 2006 industrial processing (D), and in the case of Mysłowice, the construction section (F) in 1996, and real estate management (K) in 2006).

\section{Summary and conclusions}

(1) Mining towns are characterised by a high contrast of types of the economic base of towns (indicator of the opening of the economy), which is due to the diversity of the towns studied in terms of size and functional structure. There is a high correlation between the economic base indicator and the percentage share of the mining function in towns. Centres characterised by low economic base rate (the opening of the economy) have a large share of the mining section in the exogenous function of towns. In 2009, mining accounted for $30 \%$ of the entire structure of the exogenous function of towns studied. This shows that the mining function actually contributes to the existence of many towns.

(2) Between 1996 and 2009, there was a decrease in the number of exogenous functions in nine examined towns, as well as a reduction of the share of the exogenous group size in absolute figures and in percentages, respectively in 20 and 23 towns. This demonstrates disadvantageous situation of many towns, since the deficiency of exogenous functions can mean too little inflow of external capital onto the market of a given town, which contributes to the reduction of possibilities of town development. In some cases, development of town may have a self-propelling character. Such development does not result from the growth in the basic area (exogenous functions), but from the increased attractiveness of service activities developed in town. This attractiveness may consist in diversified workforce and the existence of well-developed social infrastructure (SŁODCZYK, 2001). Such situation may concern the largest towns studied, namely Katowice, Gliwice and Sosnowiec.

(3) The restructuring process contributed to the change in the functional type of many mining towns, basing on the volume of employment in the exogenous group in particular sectors of economy. In 1996, industrial towns accounted for $79 \%$, whereas service-based towns for $21 \%$, and in 2009, industrial towns constituted only 54\% and service-based towns $46 \%$. This reflects the overall situation of the majority of towns in Poland.

(4) Industrial towns specialising in mining represent the largest group of centres; in the studied period of 1996-2009, their number decreased by two towns (from 13 to 11). This shows that mining is the main branch of business activity in many examined towns, particularly in small ones. Mining industry has also a large impact on the functional type of towns with more than 50 thousand inhabitants, such as Jastrzębie-Zdrój and Ruda Śląska. This has positive consequences in the present time, consisting in the financial stability of a town, however, the lack of development of alternative sections may negatively affect the development of towns in the future, when the activity of mines will be limited due to the depletion of deposits, geological difficulties, etc. This can be observed on the example of Wojkowice in which during the period studied the share of the exogenous group decreased by over $30 \%$.

(5) In 2009, service-based towns were mainly specialising in trade (section G). There is a small group of towns specialising in higher-order services, financial agency activities and real estate management (section J and $\mathrm{K}$ ) - this group consists of only five towns. Only three towns specialise in social services (sections L, M, N and $0)$. This means that although there is a large group of service-based towns, they mainly represent material sections, which does not indicate a high level of development of higherorder services in these towns.

\section{References}

Beaujeu-Garnier J., Chabot G. 1971. Zarys geografii miast. PWE, Warszawa: 163-170. 
Choriew B. 1965. Issledownije funkcjonalnoj struktury gorodskich posielenij SSSR ( $w$ swiazji s zadaczami ich ekonomikogeogrqaficzeskoj tipołogji). WOP, Geografia, no. 66.

Dziewoński K. 1967. Baza ekonomiczna i struktura funkcjonalna miast, Studium rozwoju pojęć, metod i ich zastosowań. IG PAN, Prace Geogr., 63, PWN, Warszawa: 38-68.

Harris Ch. 1943. A functional classification of cities in the United States. Geographical Review, 33.

Jerczyński M. 1973. Studia nad strukturą funkcjonalną miast, PAN IG, Prace Geogr., 97, Zakł. Narod. im. Ossolińskich, PAN: 54-58.

Jerczyński M. 1977. Funkcje i typy funkcjonalne miast (zagadnienie dominacji funkcjonalnej). [in:] Statystyczna charakterystyka miast. Funkcje dominujące. Statystyka Polski, nr 85, GUS, Warszawa.

Liszewski S., Maik W. 2000. Osadnictwo. Wielka Encyklopedia Geografii Świata, vol. XIX, Kurpisz Publ. House, Poznań: 161-181.

Maik W. 1992. Podstawy geografii miast. UMK, Toruń: 27-44.

Rajchel D. 2001. Przemiany struktury funkcjonalnej i bazy ekonomicznej miast śląska opolskiego. Doctoral thesis, UO, Wydz. Ekon., Opole: 166-239.

Rajman J. 1972. Klasyfikacja typologiczna miast i osiedli miejskich aglomeracji górnośląskiej okręgu przemysłowego. Folia Geogr., Ser. Geogr.-Oecon., PAN, PWN, WarszawaKraków: 23-36.
Skiba L. 1988, Czynnik ludzki w strukturze funkcjonalnej miasta przemysłowego. Prace Nauk. Akad. Ekon. im. 0. Langego we Wrocławiu.

Słodczyk J. 2001. Przestrzeń miasta i jej przeobrażenia. Uniw. Opol., Studia i monografie, 298, Opole: 55-75.

Suliborski A. 1983. Niektóre problemy badań funkcji miast w świetle podstawowych założeń koncepcji systemowej. Acta Univ. Lodz., Folia Geogr., 2: 3-16.

Suliborski A. 2010. Funkcjonalizm w polskiej geografii miast. Publ. House of UŁ, Łódź: 81-99,112-121.

Tkocz M. 2006. Przemiany funkcjonalne miast konurbacji katowickiej w latach 1989-2003, [in:] Słodczyk J., Szafran E., (ed.) Kierunki przekształceń struktury gospodarczej $i$ społeczno-demograficznej miast. Uniw. Opol., Opole: 71-83.

Walkiewicz D. 2006. Przemiany struktury funkcjonalnej miast wojewódzkich w latach 1975-1995. Publ. House of Uniw. Łódz., Łódź.

William-Olsson W. 1953. Ekonomisk karta oper Europa. Stockholm. Zuzańska-Żyśko E. 2006. Małe miasta $w$ okresie transformacji. Studium w regionie śląskim. Śląsk Publ. House, Katowice. 